\title{
IMPROVED QUALITY MANAGEMENT OF LEARNING: In MTs Negeri Model Cigugur Kuningan
}

\section{Hary Priatna Sanusi}

UIN Sunan Gunung Djati Bandung JI. A.H. Nasution No. 105 Cibiru Bandung 40614

Email: harysanusi@yahoo.co.id

\section{Abstract}

The most urgent demands in the development of quality education and relevant to the needs of the community is increased capacity. School principals should be able to give birth to innovative ideas that are useful for generating policy alternatives in building. The education system is an efficient, high quality and in accordance with the needs of society in various fields of life. Effectiveness of management functions in learning activities with the application of the principles of lesson planning, organizing functions in learning, actuating functions in learning, and monitoring functions in learning activities. Learning management application that includes lesson planning, organizing learning, learning implementation, monitoring/ assessment of learning. Learning management can be seen from the number of new students who are always growing, produce learners who excel both in academic and non academic.

Keywords: Management, Quality, and Learning Abstrak

Tuntutan yang paling mendesak dalam pembangunan pendidikan yang bermutu dan relevan dengan kebutuhan masyarakat adalah peningkatan kemampuan. Kepala sekolah harus mampu melahirkan gagasan inovatif yang berguna untuk menghasilkan alternatif kebijakan dalam membangun. Sistem pendidikan yang efisien, bermutu dan sesuai dengan kebutuhan masyarakat dalam berbagai bidang kehidupan. Efektivitas penerapan fungsi-fungsi manajemen dalam kegiatan pembelajaran dengan aplikasi prinsip-prinsip perencanaan pembelajaran, fungsi pengorganisasian dalam pembelajaran, fungsi penggerakan dalam pembelajaran, dan fungsi pengawasan dalam kegiatan pembelajaran. Penerapan manajemen pembelajaran yang mencakup perencanaan pembelajaran, pengorganisasian pembelajaran, pelaksanaan 
pembelajaran, pengawasan/ penilaian pembelajaran. Manajemen pembelajaran dapat dilihat dari jumlah peserta didik baru yang selalu bertambah, menghasilkan peserta didik yang berprestasi baik akademik maupun non akademik.

Kata Kunci: Manajemen, Mutu, dan Pembelajaran

\section{Introduction}

In the Republic of Indonesia Act number 20 of 2003 regarding the educational system of the National article 1, paragraph 1 explained that education was "conscious and deliberate effort to create an atmosphere of learning and the learning process so that learners are actively developing the potential for him to have the spiritual power of religion, self-control, personality, intelligence, character, and skills needed him, society, nation and state "(Uus Ruswandi, 2011: 5)

The development level of education was influenced by the management as a driving force in the process of education, so that in the implementation of education will never be separated from management. Due to the absence of management, education becomes apparent size, so it will be difficult to achieve the objectives that have been defined, both objectives outlined in the National Education or objectives that were defined in the institution itself.

Management according to Abdurrahmat Fathoni (2006: 27) is a typical process consists of actions starts from goal setting to supervision. Hersey and Blanchar in Syarifuddin dikutif by Furqan Syarif Hidayatullah (2013/1434: 188) confirms that the management is the process in collaboration between individuals and groups as well as other resources in achieving organizational goals. This means it can be concluded that the management of the outline is a tool to achieve the goal of optimally.

The most urgent demands in the development of quality education and relevant to the needs of the community is an increased ability to conduct research and policy analysis. School principals should be able to give birth to innovative ideas that are useful for generating policy alternatives in building. The education system is an efficient, high quality and in accordance with the needs of society in various fields of life. The headmaster of an educational leader should be able to know and understand the various positions, circumstances and what is desired by both teachers and administrative employees and other helpers. So with the good cooperation can produce a harmonious mind in school improvement efforts. The headmaster is a driving force in driving the school policy, which will determine how the goals of the school and education in general, realized. School principals are required to continuously improve performance effectiveness so that it can give a satisfactory result.

Learning is a process that consists of a combination of two aspects, namely: studying drawn to what should be done by the students, teaching oriented on what to do by teachers as a giver of lessons. Both of these aspects will collaborate integrated into an activity at the time of interaction between teachers and students, and between students and students when learning takes 
place. In other words, learning is essentially a process of communication between learners with educators and among students in order to change attitudes. Learning activities strongly related to the process of planning the science and putting people knowledgeable in a high degree, it is in accordance with the word of Allah in the Al-mujaadilah paragraph: 11 Meaning: "O ye who believe! when it is said unto you, Make room! in assemblies, then make room; Allah will make way for you (hereafter). And when it is said, Come up higher! go up higher; Allah will exalt those who believe among you, and those who have knowledge, to high ranks. Allah is Informed of what ye do. "

In the context of education, how to achieve quality education, human (principals, teachers, education personnel, other employees, students, parents or guardians of students, and steakholder in view of glasses MMT (TQM) is the customer who must be the center attentive in meeting all the needs and desires. Satisfaction learners lies in the ongoing processes and outcomes are satisfactory in the educational process. thus the quality of education is not a stand-alone but it is a unity that is interconnected and linked as a process within a system, when talking about the quality of education it will not be apart of the three elements of education, namely, input, process, and graduates. the existence of graduate educational institution is a human who is the subject and object of development which needs to be improved through education in the functions, processes, and activities that lead to the achievement of national education goals.

The fact that there is that the learning management that emphasizes the application of discipline for students to implement the learning outcomes, not only that but also supported by a learning management that emphasizes the three domains, namely: Cognitive, affective and psychomotor. The result is certainly making MTsN Model Cigugur Kuningan district has advantages in terms of knowledge, understanding and application of the lessons learned. This has become the hallmark of MTsN Model Cigugur District Brass. As well as raises some fundamental issues such as: What is the background of the management of such learning? What theoretical basis? How is the strategy? How the steps or learning management, what media, methods and tools of learning? how results have been achieved so far? If successful, what is the contributing factor?

\section{Analysis Theoritical Foundation}

Management is an art management process undertaken by the leadership (managers) starting from planning, organizing, implementation and control into a series of concrete activities to take advantage of all the related resources to achieve organizational objectives that have been defined previously effectively and efficiently.

Based on the above outline can be said that the function of the management that there should be a minimum of planning, organizing, implementing, and monitoring, to more clearly be described as follows:

1. Planning. Planning is a process to determine the activity or program activities. A planning is always related to the goals. Planning helps us to know what to do. 
2. Organizing. Organizing is the grouping of tasks and the division of the group that carried out by a leader to its employees which aims to establish an organized container and make it easier to achieve objectives secar performance effectively and efficiently.

3. Implementation. Implementation is the most important management functions. In the function of planning and organizing more related to aspects of the management process, while the actuating function even more emphasis on activities that are directly related to people in the organization in a single destination.

4. Control. Supervision is the management functions related to monitoring, observation, coaching, and guidance made by a manager of all elements into human resources and other resources in the organization he leads.

Supervision is an activity that is done consciously with based on rational thought that has been required and appropriate normative patterns of behavior that apply in a particular community, so that the effectiveness and efficiency of a job in a management can be achieved. (Makmur, 2009: 117-118)

In Act number 20 of 2003 on National Education System, learning is a process of interaction of learners with educators and learning resources in a learning environment.

1. Components and Characteristics of Learning Interactions

Langeveld in Yayah Rokayah in an educational situation that there are elements of integrated: (1) the purpose of education (2) educator (3) children dididk (4) protege relationship and pendididk (5) material pendididkan (6) ratings (7) socio-cultural context. (Makmur, 2009: 117-118)

The components / features that allows the interaction of learning has kesamaaan. As for the components of learning which will be described below in detail is the purpose of learning, educators, students, materials / learning materials, methods, tools and assessment / evaluation of learning that supports the achievement of educational interaction. This will be described below in detail.

2. Aim

Dotted focus on the above opinion can be concluded that the educational interaction in learning is a process of reciprocal relationship that has the general purpose for mature students to be independent, it can find its establishment as a whole. While the specific interaction of interest in accordance with this discussion is to develop or improve performance, especially in the field of education which in this case is through learning.

3. Educator

In carrying out the study, the role of educators is very important in the learning process, because it has to determine the direction of learning. As for who is responsible for education in schools and in the community are teachers as educators, while in the family who became educators are parents.

4. Protege

Protege in the search for values of life, must get fully the guidance of educators. According to Islamic teachings children are born in a state of weakness and holy, while those around them will give you the style and color of the values of life to religious education students.

5. Education material 
Educational materials is the substance to be dismapaikan in the process of educational interaction component is a device connecting communication between educators and students in the learning process. (Saiful Bahri, 2006: 17)

Educational materials provided by educators as a responsible person in the organization of education, include berbagaiaspek. As for the material to be developed it is physical education, skills education (intellectual), education education divinity decency, beauty education and civic education. (Ngalim Purwanto, 1982: 187)

6. Methods and Tools Education

To achieve the goal of education requires a variety of methods and tools to assist in the implementation of education. The meaning of education according to the method is a method used to achieve the objectives set in education.

7. Assessment / Evaluation

Evaluation in English known as Evaluation is a systematic process to determine or make a decision to what extent the program objectives have been achieved.

Improving the quality of school as suggested by Sudarwan Danim, (Djaali and Pudji Mulyono, 2008: 55), is to involve five dominant factors:

1. Leadership Principals; principals must possess and understand the vision clearly working, able and willing to work hard, have a high working encouragement, perseverance and steadfast in the work, provide optimal service and a strong work discipline.

2. Students; approach that should be done is a "child at the center" so that the competence and ability of students can be dug so that the school can inventory the existing strengths in students.

3. Teachers; involvement of teachers to the maximum, with increasing kopmetensi and the profession of teacher in seminars, MGMP, workshops and training so that the results of the activities implemented in schools.

4. curriculum; curriculum; Their curriculum is fixed but dynamic, can allow and facilitate quality standards expected, and goals (goal) can be achieved to the maximum;

5. Cooperation Network; network cooperation is not confined to the school and community environment alone (parents and community) but with other organizations, such as companies / agencies so that the output of schools can be absorbed in the world of work.

\section{Research Method}

The approach used in this study is qualitative with descriptive method. According to Moleong (2014: 2), a qualitative approach is a research procedure that produces descriptive data in the form of written or oral words from people and observable behavior; the approach is directed at the background and the individual holistically. This study is not intended to test hypotheses but only objectively describes and what is the improvement in the quality management of learning in the MTs Negeri Model Cigugur Kuningan. Data collection techniques are carried out by interview, observation, and documentation studies. The 
interview technique using the standard open interview model; that is, the teacher as the key informant knows that they are being interviewed and knows the purpose and purpose of the interview. The observation method used by the researcher is observational role, meaning that the researcher participates in the implementation of activities carried out at the MTs. Documentation study techniques can be in the form of writing, drawing, or monumental works from someone, documents collected are chosen that are in accordance with the purpose and focus of the problem. Whereas in analyzing the data used is analysis with merely descriptive interpretation.

\section{Findings and Discussion}

\section{Policy Analysis Principal in Improving the Quality Management of Learning.}

MTs Model Cigugur is one of the madrasah is located in Kuningan, West Java. He was in the area Cigugur, a district adjacent to the district, with the geographical conditions are quite high in the bottom of the slopes Ciremai. The location is in a complex area of education. Therefore, in these locations stand Madrasah Aliyah Negeri (MAN) Cigugur and Islamic colleges (STAI) al-Ihya Brass. Establishment, in addition to realizing the aspirations of the Muslim community on Islamic education, linked also with symptoms of Christianity in the area. Cigugur, in those years, referred to as the target area Christianization of society. This can be evidenced by Goa Maria sites located around the area, also Dutch Christian cemetery which until now stood firmly on the side road leading research location. In this context, MTs Model Cigugur become bastions of Muslim groups from proselytizing movement that developed at this time. The results of interviews with the Head MTs description, Drs. H. Iman Nuryaman, MA, in the area around the complex MTs, spread a large number of Christian families are more numerous than Muslim families.

Efforts to improve the quality of learning in MTsN Model Cigugur, both on improving the curriculum, improving the professionalism of teachers, fulfillment, infrastructure and educational empowerment, has been, is and will be implemented continuously. MTsN Model Cigugur must develop a vision according to the researchers need attention: first, the primary school were always always be the number one destination by the community for schools in communities grow and thrive by the community. Second, the superior and outstanding schools that prints the nation's children who have the ability and skills were sufficient and able to face the challenges and changing times. The third noble personal formation of students is good, that the school is able to create a nation that faith and fear of Allah SWT. Fourth of desire and the first choice of the people. Associated with the policies adopted by the principal in order to improve the quality of learning associated with the policies adopted by the principal in order to improve the quality of learning, there are some things that implemented such as:

a. The involvement of all components: teachers, employees, principals in achieving competitive advantage they all should be empowered to improve the quality of the graduates together to solve problems. Improve the education process and satisfy the customer. School principals must lead MTsN Model Cigugur school with relevant examples. For example the use 
of tools, languages, data and recommend the concept of quality management of learning. The principal's role as an adviser, infrastructure, and leaders should not be ignored. That is, he must understand and memanaj continuously to achieve the expected improvement of education quality. The leader is a determinant of organizational success in achieving objectives can be used as a model and be able to inspire all components MTsN Cigugur Model. From this the need for a leader who can bring MTsN Cigugur for more advanced models emphasis on quality and the quality of its output so as to survive in the midst of the competitive world of education today.

b. Improving the quality of teachers.

There is some support for improving the quality of teachers and employees MTsN Cigugur Models include:

1) Training MGMPs to improve the quality of teaching and teachers.

2) Training of management and leadership educators.

3) Workshop on improving the quality of teaching.

4) Hold regular discussion board of teachers every month.

5) Encourage teachers to continue their studies to a higher level for those who have not (SI).

Some of these activities are expected to improve the quality of teachers and employees in providing services to the customers of education, namely: community by holding internal improvements it is expected that all customers are satisfied with the results obtained. So believe in the community of MTsN Model Cigugur stay awake because of the quality produced by MTsN Model Cigugur.

c. Curriculum

The curriculum can be interpreted as a means to achieve educational goals. Thus the curriculum is an important tool in the educational process. And in MTsN Model Cigugur set hidden curriculum as supporting the curriculum.Design curriculum applied in MTsN Cigugur Model which is the special character and makes MTsN Model Cigugur able to compete in the midst of competition at this time. No curriculum is said to be the most appropriate and corresponding good, because the curriculum itself must adapt to the changes and developments as well as the demands of society. In addition to the factors that have adequate support in order to achieve quality education MTsN Model Cigugur also must prepare for changes from time to time shift.

d. Facilities and infrastructure.

MTsN Model Cigugur own facilities and infrastructure are adequate and used optimally in order to achieve the ultimate goal of education is expected. MTsN Model Cigugur also provide the best service for the convenience of students and the learning process is a process to produce a good quality school. The facilities were used as well as the teaching workforce owned MTsN Model Cigugur is expected to print output quality, both in Islam and science and give satisfaction to customer education.

While in improving the quality of schools, the policies being enforced by the principal in order to anticipate the future in order to compete and survive in the face of competition education are as follows: 
1) Increasing continuously, purpose and focus $M T s N$ Model Cigugur is continuous quality improvement both in terms of service, management, teaching and learning activities, measures and policies should be oriented towards improving the quality and competitiveness at the other school.

2) The communication was good from all aspects and to cooperate with anyone. Good communication system should be able to accommodate all the aspirations of all parties, both of the parents, the teachers, employees, the community and the students. If this system can be optimized, the school management can be run properly because of all the ideas and aspirations can be accommodated and executed secar together.

3) Developments in MTsN Model Cigugur arguably different from other educational institutions, it can be seen from the activities of teachers and employees at the agency. Each teacher always make the process of learning it well, so that inspiration materials delivered more effectively so that students are not bored and tired. Teacher always accompany the students to learn it is intended that the child can be conditioned and able to follow the lessons delivered by teachers so that teaching and learning process more optimal.

4) The facilitator supporting the smooth management of the quality of teaching in MTsN Model Cigugur.

a) Human resources qualified and professional, support the implementation of quality management of learning.

b) The existence of the will and the willingness of students to learn and interested in the development and improvement of the quality of religious.

c) Support and commitment in the implementation of learning management MTsN Cigugur Model. It was seen by the school effort to try to create an atmosphere conducive and Islamic schools were decanted from the vision, mission.

d) There is support, help, input from the committee to the learning process.

Responsibility (accountability) Schools are required to have both society and government accountability. It is a blend of commitment to the standards of success and the expectations / demands of parents / community.

\section{Analysis of the implementation of the Quality Management Model of Learning MTsN Cigugur}

a. Planning of learning.

This relates to the planning of activities to be achieved in the future. In planning activities set various resources, so that the results achieved in accordance with the expected goals. Here educators must have the creativity in developing material according to the competency of learners and the development of the surrounding environment.

The learning process in MTsN Model Cigugur done in a way to realize a design that has been made in the syllabus, semester program, the annual program, the program lesson plans, and education calendar. In planning this 
learning educators always give the best for learners to improve quality in the schools so that the outputs produced to be more qualified.

MTsN Model Cigugur as educational institutions have to carry out planning well in management, particularly in the areas of learning. The lesson plans have been said better view indikaror-indicators, namely: at the beginning of each new school year party MTsN Model Cigugur hold regular meetings in order to evaluate all forms of activities that have been done over the past year, and discuss programs for years to come.

b. Organizing learning.

In organizing the learning educators in MTsN Model Cigugur should be able to motivate learners and creating a classroom atmosphere conducive to achieve the learning objectives that have been set. In the process of learning the relationship between educators and learners can work well, it is because educators in MTsN Model Cigugur able to portray itself as:

1) Fasilitataor, educators facilitate each student's needs, especially those related to the learning process.

2) Managers, educators here a position as manager of the learning process so that the direction and goals can be achieved.

3) Motivator, educators are people who give lessons to students, to the educators should provide motivation for students to achieve a better future.

4) Evaluator, the learning process is carried out aims to provide the knowledge, mastery of the material that has been taught and changing attitudes students to become better. Mastery learning materials measured by the evaluation.

By organizing activities undertaken in the Cigugur Model MTsN, according to researchers are in accordance with the theoretical framework. Activities in the learning process MTsN Cigugur Model looks smooth and conducive atmosphere. Organizing teaching in MTsN Model Cigugur also has done well this is proven by the enthusiastic learners in learning to follow because it is supported by an effective class, attractive, comfortable, clean and fun for the development potential of learners to motivate them to study harder.

c. Implementation of learning.

Implementation of learning in MTsN Model Cigugur done with the following steps:

1) The study was based on potential developments and conditions of learners to master the lesson.

2) Learning to do with a conducive atmosphere so that the relationship between educators and learners mutual respect.

3) The approach is performed with multistategi approach and multi-media learning resources and adequate technology and utilization of the environment as a learning resource.

4) Learning that do allow students to get service that is improvement, enrichment, in accordance with the potential, progress and conditions of learners.

In learning activities in MTsN Model Cigugur methods used are varied ie, lectures, question and answer, demonstration and discussion. These methods are very helpful in presenting material to students so that they are easier to 
digest the lessons that have been submitted so that the learning process can run effectively. It was intended from the achievements of the students both academic and non-academic. It is fitting MTsN Model Cigugur strive for better and maintain what has been held in order to compete with other institutions.

d. evaluation of learning

Learning implementation is successful visits by the evaluation. Things to consider in the assessment is the principle of continuity, ie educators continuously follow the growth, development and change of the learner. The evaluation results can be used as a reference to improve the learning programs, increasing the level of mastery of learners and monitor the success of learning that has been applied.

In the evaluation of learning in MTsN Model Cigugur, local communities were given information about how the results achieved by students who studied at MTsN Model Cigugur, it is a form of school cooperation with local communities. This has been done that is by carrying out an assessment of the performance of learners. As for the assessment includes assessment of the results and assessment process consists of three domains: cognitive, psychomotor and effective.

e. Learning motivation.

Achievements will not be as expected without a motivation and encouragement from all parties, both principals, teachers, and employees. In the teaching and learning activities headmaster always motivate teachers so that the overall motive power within themselves teachers lead learning activities which ensure the continuity of the learning activities can reach the desired destination and can obtain optimal results.

f. Learning facilities.

So far the existing facilities in MTsN Model Cigugur seen by the researchers could be said to have qualified where each classroom is equipped with an LCD TV. There is also the science laboratories, language, computer lab that can be used for internet and also a hot spot area that can be used to obtain the information needed, as well as a library that can be used students as a place to acquire and increase knowledge.

g. Empowerment.

The school principal MTsN Model Cigugur already done empowerment of teachers and employees, which can be seen here on the role of the principal that every teacher training / worksop associated with an increase in the quality of learning as MGMPs, socialization and Curriculum SBC 2013, computer training and improvement of teaching creativity. With the teachers and staff are professional, the learning process to be effective, efficient and focused.

Teachers in MTsN Model Cigugur are young and have a democratic and advanced thinking. With the quality possessed by each teacher will influence also on the quality of the learning process that took place and were able to bring the school to the level of better quality.

From the description of the implementation of the learning is done in MTsN Model Cigugur we can see the resulting quality of learning. Quality can be seen from the "input" which include: students, faculty, administrators, funds, facilities, curriculum, library books, lab and learning tools, "process" includes the management of institutions, programs of study, teaching and learning activities, 
academic interaction. While "results" include: graduate, behavioral / ahklak, results, other performance.

a. Input learning.

With the quality of learning, the learning process will be done smoothly. With the professional teachers are expected to provide the knowledge, the materials to the learners more steady, and the students got a lesson from a competent teacher. Teachers, principals, employees are resources that are included in the educational input. If the input is good, the quality of learning will be good. All educational inputs that would make the quality of the school is good or bad depends on the quality of the learning process takes place in the school environment.

b. Learning process.

When learning providers have good performance, it will create a school climate that is conducive. MTsN Model Cigugur expected to have a neighborhood association, relationship management, behavioral patterns, and all existing regulations can be implemented. With the school climate conducive, will certainly have an impact on a comfortable learning atmosphere. School quality can not be seen from the output, but also the views from the learning process is carried out to create an atmosphere that is safe, comfortable, and conducive to learning objectives can be achieved.

c. Out put learning

In terms of output quality, MTsN Model Cigugur have a good quality, both in science and technology and IMTAQ. Referring to the quality of the output, of course can not be separated from the function of the planning that has been done. Activities planned any given period of time (whether the end of the semester, the end of the year, 2 years / 5 years, even 10 years).

Achievement / learning outcomes such as academic test results (eg, daily tests, general tests, UN), it can not be achieved without the support resources, ie resources. According to researchers MTsN Model Cigugur have set up all the resources according to local needs. Guru is one important component in the educational institutions that will be able to realize the purpose of learning, competence and professional teachers are the driving factors of achievement of the quality of students.

Success or failure of the quality of teaching in MTsN Model Cigugur can be measured by the level of academic achievement and non-academic that has been produced by learners, the school here berkuwajiban to lead learners towards the desired objectives. In order to improve the quality of teaching principals have no desire other than the students have a greater ability academic field, they also have good morals. It required the cooperation of all the components that exist in schools that: principals, teachers, students, and employees to be responsible in order to realize what you have planned.

\section{Conclusion}

Principals in improving the quality of learning management role as educational leaders have succeeded in realizing the vision, mission and objectives that have been formulated. In making policy principals have been referring to the components in the formulation of policy. Planning includes learning substance taken in the education level in three years starting from 
class VII to XI. In terms of lesson planning more attention and emphasis on learning curriculum as described above and simplified through the RPP in each subject made by each subject area teacher.

Organizing done by the principal as the manager. Headmaster carry out the functions and duties as a leader to define and divide the duties, rights and responsibilities in relation to any personal work within the agency appropriately based on abilities and educational backgrounds of human resources as an educator in the school. Implementation of the quality of learning management implemented optimally, it is proven by the learning activities carried out so far can run smoothly and produce graduates in accordance with what is expected. Evaluation, the final stage in policy making is evaluation. In the evaluation produce policy-relevant knowledge about the discrepancy between the performance of policies are expected to be produced. Success or failure of a lesson can be seen from the inputs, processes and outputs produced from the school. Classroom atmosphere conducive to make students comfortable to receive lessons.

\section{Bibliography}

Djaali dan Pudji Mulyono. 2008. Pengukuran Dalam Bidang Pendidikan. Jakarta: Grasindo

Djamarah, Syaiful Bahri. 2006. Strategi Belajar Mengajar. Jakarta: Rineka Cipta

Fatoni, Abdurrahman. 2006. Organisasi dan manajemen sumber daya manusia. Jakarta: PT Rineka Cipta

Hidayatullah, Furqon Syarif. Media Pendidikan (Jurnal Pendidikan Islam).volume XXVIII, No, 2.2013/1434.

Moleong, Lexi J. 2010. Metodologi Penelitian Kualitatif. Bandung: PT. Remaja Rosdakarya

Makmur. 2009. Teori Manajemen Stratejik. PT. Reflika Aditama. Bandung

Purwanto, Ngalim. 1982. IImu Pendidikan Teoritis dan Praktis. Bandung: Rosdakarya

Ruswandi, Uus, Badrudin. 2010. Pengembangan Kepribadian Guru. Bandung: CV Insan Mandiri 